\title{
Mediatized participation in European media systems*
}

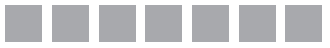 \\ Dina Vozab \\ ORCID: 0000-0001-8718-2553 \\ Zrinjka Peruško \\ ORCID: 0000-0002-7990-0997
}

UNIVERSITY OF ZAGREB, CROATIA

DOI: $10.19195 / 1899-5101.11 .2(21) .3$

\begin{abstract}
This article explores patterns of mediatized participation of European citizens and the way they differ across different media systems, in a multilevel, cross-national comparative research design. Mediatized participation is operationalized as audience practices on the Internet. The media system is conceptualized through the theoretical model of digital mediascapes, which applied to 22 European Union countries produced three clusters/media systems. The audience data are from representative online surveys in 8 eastern and western European countries $(\mathrm{N}=9532)$ collected by the authors and their research partners. Factor and cluster analyses were performed showing types and patterns of mediatized participation. Hierarchical multiple regression analysis and ANOVA were performed to relate the individual level variables to the macro-level clusters of digital media systems. The article shows audiences in the more mediatized, Western cluster are more engaged in participatory practices in comparison to audiences in the Eastern/Southern cluster of European countries which show more extensive information consumption practices.
\end{abstract}

KEYWORDS: mediatized participation, comparative research, media audience, media system, Internet, Europe.

\section{INTRODUCTION}

What is mediatized participation and how is it manifested in contemporary European media systems? Mediatization is here understood broadly as those changes in social practices that are related to the media (cf. Hjarvard, 2008; Krotz, 2014; Couldry, 2014). Mediatized participation would then be participation that is changed by the media, or that happens in relation to the media. The affordances of digital

* An earlier version of this paper was presented as "Mediatization of Political Engagement in Digital Mediascapes: Comparing European Online Audiences", at the ECREA Communication and Democracy Conference, CBS, Copenhagen, 9-10 October 2015. 
media - interactivity, modularity, sharing and the possibility of transcoding, archiving, replication \& redistribution of content on the web (Manovich, 2001; Jenkins 2004; Schulz, 2014) support more active participative roles of audiences who are

no longer confined to being passive consumers of standard political journalism, statements by party and government officials but can react to official sources and voice alternative positions in various new media spaces. (Schulz, 2014, p. 63)

Mediatization (Esser \& Strömbäck, 2014; Mazzoleni \& Schulz 1999; Strömbäck, 2008) especially in its 2.0 rendition (Mazzoleni, 2014), thus influences not only the formal or institutional actors, but also changes the character of audience participation to include practices of "networking, time-shifting, sharing content, co-creating media products, and mashing-up messages" (Schulz, 2014, p. 62).

In this article we investigate the mediatized participation of European audiences operationalized as their practices on the Internet. We use the term 'mediatized participation' to describe social practices which are extended, substituted, amalgamated, or accommodated to media form and logic in the process of mediatization (Schulz, 2004), and which are characterized by the audience's active role in participation and interactivity through media. Since media environments in which practices take place differ, and mediatization as a dynamic process changes across time or countries (Strömbäck, 2008), we intend to test the influence of the structural institutional context of the media system on media and communication/participation practices of citizens/audiences in a multi-level cross-country comparative research design. Before proceeding to describe the empirical part of the article, let us first briefly review the notion of participation in relation to audiences and the media.

The 'participation paradigm' in audience research argues that audiences are more active in media selection and have deeper interaction with media texts and technologies (Livingstone, 2003, p. 27). The participative audiences paradigm is partly inspired by the convergence culture theory in which audiences are perceived as more autonomous "prosumers" and networked actors (Cardoso, 2011; Castells, 2009; Jenkins, 2006; Shirky, 2008) and explores the possibilities of audience interaction with media content, other media users, user generated content, and other different types of media participation (Carpentier, 2011; Livingstone, 2003, 2013; Livingstone \& Das, 2013). While the term "media audiences" is more commonly used to describe practices connected to consumption of media content, the term media user includes a much wider spectrum of media participation practices: consumption and sharing of content, information seeking, communication and discussion with other media users, play, shopping, work, or education (Livingstone, 2003). Audiences media participation includes "participation in media production, participation in society through the media, and interaction with media content where 
it can be "articulated within the contexts of community and alternative media, television talk shows and reality TV, and new media" (Carpentier, 2011, pp. 64, 70).

Media participation can also be considered a media practice, a term used to analyze audience practices through the sociological lens of practice theory, defining them as human action with a sort of regularity that becomes a part of the routine or lifestyle, that is social and derives from human needs (Couldry, 2012, p. 33). Couldry (2012) describes media practices, some of which are deeply embedded in digital media: searching and search enabling, showing and being shown, presencing, archiving, keeping up with the news or other complex media-related practices. Media participation can also be analyzed through the uses and gratifications theory perspective, as participation which can supplement, or be a functional alternative to 'offline' activities (Papacharissi \& Mendelson, 2011). Papacharissi and Mendelson (2011) found different types of uses and gratifications for participation in social media which are used for information, entertainment, and instrumentally for building social capital.

Some of the mediatized social practices can be seen as political, in the extended or maximalist definition of politics which shifts the interplay of media and democracy to questions of culture (Carpentier, 2011; Dahlgren, 2005). Particularly useful in exploring media-related participation practices is the notion of "public connection" of citizens to public life (Couldry, Livingstone, \& Markham, 2007) which extends the boundary of the political by focusing on the media consumption that connects citizens with the public sphere, with the issues that are common, and which demand common solutions and actions (Couldry et al., 2007). While many authors use the term engagement and participation as synonyms, some authors divide online engagement into two main types of activities: participation with predominantly horizontal modes of actions like blogging, posting comments, joining groups in social networks, and information consumption or exposure to online news, including both the legacy media on the Internet, Internet born media, or social networks or other sources (Anduiza, Jensen, \& Jorba, 2012). In this article we are interested in the mediatized participation irrespective of whether its purpose is political (even if the consequences may be political, although this is outside the scope of this paper). Also, the distinction between participation and information consumption stems from a pre-mediatized world, when practices of information searching, retrieval, or sharing were not known. We will see whether these practices are differentiated or form similar patterns in the online environment.

While the literature review shows different notions about media-related participation practices, the research evidence is disconnected and lacks comparability. This brings us to our first research question:

- RQ1: What are the patterns of mediatized participation of European online audiences? 


\section{STRUCTURAL ANTECEDENIS OF MEDIATIZED PARTICIPATION: DIGITAL MEDIASCAPES}

Earlier research shows that considering the media system or other institutional contexts for (predominantly news-related) audience practices, adds significant explanatory power to understanding of media use (Aalberg et al., 2010; Altheus et al., 2009; Blekesaune et al., 2012; Elvestad \& Blekesaune, 2008; Curran et al., 2009; Meulemann, 2010; Shehata, 2010; Shehata \& Strömbäck, 2011). All the mentioned studies draw on the media systems model by Hallin and Mancini (2004), developed to take account of the relationship between the practice of journalism and politics in Europe and North America. Comparisons are made based on the original country groupings by Hallin and Mancini, which have only been partially supported by the empirical operationalizations in Peruško et al. (2013) and Brüggemann et al. (2014) (most doubt was placed in the existence of the liberal media system which does not appear in either study).

For describing the media environment and the macro-structural antecedents of mediatized participation, we employ in this article the theoretical model of digital mediascapes and its empirical operationalization developed in Peruško et al. (2015). The model of digital mediascape was constructed to answer to the changed environments of contemporary media, and defined with four main dimensions: institutional inclusiveness, the digital media market, media culture, and globalization (Peruško et al., 2015).

Cluster analysis performed on 22 East and West European media systems resulted in three European digital mediascape clusters: the Nordic ${ }^{1}$ cluster, the Western cluster, and the Eastern/Southern cluster. ${ }^{2}$ The Western cluster includes countries from all three Hallin and Mancini (2004) models (might this be, in disguise, the convergence to the commercialized liberal model they were expecting, and which shows after the media system is appropriately described to reflect contemporary frameworks of media?)

Central and East European countries in the Eastern/Southern cluster share with Greece and Portugal similar structural characteristics of lower (than average of all included countries) political and social inclusiveness, lower globalization, lessdeveloped digital media markets and less open creative economies with higher TV concentration. The Nordic cluster has the highest values on the inclusiveness dimension, most developed digital media market, middle levels on the creative economy dimension, and middle levels of the concentration of the television audience market. The Western cluster shows high inclusiveness and a developed media market, the highest values in the openness of a creative economy, together with a low

1 The Scandinavian label from Peruško et al. (2015) was replaced by a more appropriate Nordic.

2 Post-socialist democracies - Bulgaria, Croatia, Czech Republic, Hungary, Poland, Romania, Slovenia, Slovakia - form one cluster together with Greece and Portugal. The second cluster includes Austria, Belgium, France, Germany, Ireland, Italy, Netherlands, Spain and UK, while the Nordic cluster - Denmark, Finland, Sweden — remains separate. 
concentration of television audience markets, signifying the highest levels of television audience fragmentation associated with advanced media system commercialization. The institutional inclusiveness dimension plays a role in system differentiation, alongside the economic and technological development and global connectivity that we can see as the backdrop for the differences in the structures of the digital mediascapes.

Whether macro-institutional structures of media systems influence mediatized participation is still an open empirical question. Therefore, our second research question is framed as follows:

- RQ2 How does mediatized participation differ across different digital mediascapes?

\section{RESEARCH DESIGN}

In this study, we employ a multi-level analysis to show the influence of media systems on mediatized participation. Research so far dealt with the usual socio-demographic variables at the individual level (gender, age, education, income) along with political and media use characteristics as explanatory variables. Comparative studies are very rare, especially those that include Central and Eastern European countries. Shehata (2010) analyzed influences of television and newspaper use on political participation in four Nordic countries, with the media systems framework of Hallin and Mancini (2004) as explanatory context but without engaging any structural characteristics of media systems. The only similar study is Nir (2012) who uncovered the influence of structures of political systems on political discussion in a multi-country comparative design. To the best of our knowledge, this is the first cross-country multi-level comparative study examining the impact of the structural level of media systems on mediatized participation.

The structural level is represented by the model of the digital mediascape by Peruško et al. (2015).

Mediatized engagement is operationalized by a set of ten variables that measure using the Internet for different purposes, including different participatory practices as well as information consumption practices. The question was posed in the surveys in the following way:

Please think of yesterday and any use of the Internet you made yesterday. How much time did you spend on the following things?

Getting news;

Writing and reading e-mails;

Downloading music, films, and podcasts;

Playing computer games online;

Using social network sites;

Online chat;

Reading entries at debate sites/ blogs; 
Writing entries on debate sites/ blogs;

Using websites concerning my interests and hobbies;

Online shopping/banking/travel reservation etc.

Respondents were asked to answer in the number of minutes they spent on each Internet practice, including non-use and 'don't remember'.

This article proceeds as follows. After introducing our data, we present the empirical part of the study in which we first test the dimensions of mediatized engagement, and then the influence of the system level structures on mediatized participation and information consumption. Preliminary conclusions are presented in the final section.

\section{DATA}

The survey data is from the COST comparative research project on "Audiences across media" including eight European countries: Belgium, Croatia, Denmark, Germany, Hungary, Italy, Poland, and Portugal, in which the authors were participants. ${ }^{3}$ The combined sample consists of 9532 respondents (app. 1200 respondents in each country dataset). Data collection was conducted by market research agencies in each country, as an online survey, from February to April 2013. The samples are representative in terms of age distribution of online users for each country and were balanced in terms of gender and geographical regions. Participating partners funded national surveys and national datasets were merged in a single dataset for comparative research. See Jensen and Helles (2015) for an overview of the project, project partners, and questionnaire.

\section{RESULTS AND DISCUSSION}

The largest number of online audiences in media systems included in the study use the Internet for e-mails (88.1\%) news consumption (70.5\%) and for online social networking (68.2\%), visiting websites concerning interests and hobbies (55.4\%), while online shopping (34.5\%), reading entries at debate sites and blogs (33\%), playing online games $(32.7 \%)$, online chat $(22 \%)$, downloading music, films and podcasts (18.7\%), and writing entries on debates sites and blogs (15.7\%) engages lower numbers.

\section{Genres of mediatized engagement}

An exploratory principal component factor analysis was performed to discover underlying dimensions or latent constructs that account for the various methods of internet use. Factor analysis was performed with time spent on the ten listed online practices. The rotation method was Varimax, with Keiser Normalization.

3 As Israel clusters separately in regard to the digital mediascapes, the Israeli sample was omitted from this analysis to simplify the theoretical explanation. 
Factor analysis was performed in the composite sample of all eight countries. Table 1 presents the two-factor solution based on ten Internet practices, which explains $40.21 \%$ of the variance.

Table 1. Rotated factor solution of 10 variables (time spent)

\begin{tabular}{|l|c|c|}
\cline { 2 - 3 } \multicolumn{1}{c|}{} & \multicolumn{2}{c|}{ Component } \\
\cline { 2 - 3 } \multicolumn{1}{l|}{} & 1 & 2 \\
\hline Writing entries on debate sites, blogs & .703 & - \\
\hline Writing and reading e-mails & .662 & - \\
\hline Getting news & .619 & - \\
\hline Reading entries on debate sites, blogs & .588 & - \\
\hline Using websites concerning my interests or hobbies & .574 & - \\
\hline Online shopping, banking, travel reservation etc. & .400 & - \\
\hline Playing computer games online & - & .728 \\
\hline Using social network sites & - & .682 \\
\hline Downloading music, films, or podcasts & - & .577 \\
\hline Using chat programs & - & .522 \\
\hline
\end{tabular}

Source: Authors.

Factor analysis shows that time spent on online practices diverges along the public interest vs. entertainment divide that we are used to seeing also in legacy media content and use, and that online practices do not divide along the lines of (more active) participation and (more passive) information consumption. Public connection practices are oriented to one of the basic media functions of environment surveillance and purposeful, instrumental, activities (shopping, banking), including more participative or active practices of writing and reading entries on debate sites and blogs, sending and receiving e-mails, getting news. Personal connection practices include entertainment and personalized activities like online gaming, using social network sites, downloading music, films, and online chatting.

The latent dimensions defined by factor analysis were saved as factor scores. These factor scores were used as dependent variables in hierarchical multiple regression, by which the influence of individual and structural level factors on the variation of dimensions of Internet use were analyzed. Individual level variables were gender, age, education, income, and urbanity. ${ }^{4}$ The independent variables measuring the

4 Age is an interval variable ranging from 1 to 4 . Gender $-1=$ male, $2=$ female. Urbanity a four scale variable ranging from 1 (Farm/home in a countryside/country villages) to 4 (a big city). Education level is a seven scale variable ranging from no formal education to a doctorate. Income was a three scale variable with values below average income, average income and above average income. These were recoded to dummy variables to address average and above average income in reference to below average income. The answer don't know/don't want to answer was treated as system missing. 
structural level of digital mediascapes referred to the clusters defined in a previous study by Peruško et al. (2015). Croatian, Hungarian, Polish, and Portuguese audience datasets were combined to form the Eastern/Southern cluster, Belgian, German, and Italian to the Western cluster, and Danish to the Nordic cluster. The digital mediascapes variable was dummy coded for the regression analysis to the Western and Nordic cluster with the Eastern/Southern cluster as the reference category.

Adding structural-level media system variables to the model explains a greater amount of the variation for both public connection and personal connection online practices. Individual variables explain $0.3 \%$ of the variation in public connection Internet uses, while a combination of individual and structural variables explains $4.8 \%$. Individual variables explain $7.8 \%$ of the variation in personal connection Internet uses, while a combination of individual and structural variables explains $8.2 \%$.

Table 2. Regression analysis - individual and structural level predictors of online public connection and personal connection practices

\begin{tabular}{|c|c|c|c|c|c|c|c|c|c|}
\hline \multirow[b]{2}{*}{ Model } & & \multicolumn{4}{|c|}{ Public connection } & \multicolumn{4}{|c|}{ Personal connection } \\
\hline & & B & SE & Beta & & B & SE & Beta & \\
\hline \multirow{7}{*}{1} & (Constant) & 0.012 & 0.200 & - & 0.950 & 1.282 & 0.167 & - & 0.000 \\
\hline & Urbanity & 0.000 & 0.027 & 0.000 & 0.990 & 0.002 & 0.023 & 0.003 & 0.923 \\
\hline & Average income & 0.032 & 0.087 & 0.012 & 0.715 & -0.021 & 0.073 & -0.009 & 0.770 \\
\hline & $\begin{array}{l}\text { Above average } \\
\text { income }\end{array}$ & 0.028 & 0.077 & 0.013 & 0.720 & -0.102 & 0.065 & -0.054 & 0.116 \\
\hline & Gender & -0.150 & 0.063 & -0.073 & 0.016 & -0.057 & 0.053 & -0.032 & 0.282 \\
\hline & Age & 0.002 & 0.003 & 0.018 & 0.563 & -0.017 & 0.002 & -0.214 & 0.000 \\
\hline & Education & 0.038 & 0.031 & 0.040 & 0.214 & -0.136 & 0.026 & -0.161 & 0.000 \\
\hline \multirow{9}{*}{2} & (Constant) & -0.160 & 0.197 & - & 0.417 & 1.237 & 0.168 & - & 0.000 \\
\hline & Urbanity & 0.005 & 0.027 & 0.006 & 0.850 & 0.004 & 0.023 & 0.005 & 0.867 \\
\hline & Average income & 0.001 & 0.085 & 0.001 & 0.986 & -0.032 & 0.073 & -0.013 & 0.666 \\
\hline & $\begin{array}{l}\text { Above average } \\
\text { income }\end{array}$ & 0.001 & 0.075 & 0.000 & 0.990 & -0.109 & 0.065 & -0.058 & 0.093 \\
\hline & Gender & -0.139 & 0.061 & -0.068 & 0.024 & -0.051 & 0.053 & -0.029 & 0.331 \\
\hline & Age & 0.003 & 0.003 & 0.031 & 0.313 & -0.016 & 0.002 & -0.209 & 0.000 \\
\hline & Education & 0.055 & 0.030 & 0.057 & 0.071 & -0.133 & 0.026 & -0.158 & 0.000 \\
\hline & Western cluster & 1.240 & 0.168 & 0.215 & 0.000 & 0.375 & 0.144 & 0.074 & 0.009 \\
\hline & Nordic cluster & 0.525 & 0.507 & 0.030 & 0.300 & -0.148 & 0.434 & -0.010 & 0.734 \\
\hline
\end{tabular}

Source: Authors. 
The results of the regression analysis are presented in Table 2. On the individual level, only gender is a significant factor influencing online public connection practices, with men being more likely to use the Internet for these "useful" purposes. System level influence is far more important in explaining the online public connection practices. Membership in the Western cluster is more likely to lead to more extensive use of the Internet for surveillance and public connection purposes. We will revisit these interesting findings in the conclusion.

Age and education are significant variables influencing the personal connection genres of online engagement, including entertainment and social Internet use, with younger and less- educated audiences being more likely to use the Internet for leisure or entertainment. Membership in the Western cluster also leads to the longer use of the Internet for entertainment and personal social interaction.

\section{Participation and information consumption in the digital environment}

News consumption, reading and writing blogs and participating in debate sites and online social networks can be seen as actions that are meaningful for the success of the public connection as posited by Couldry, Livingstone, and Markham (2007). Reading news connects the public to the broader common issues outside of their personal sphere, as well as reading blogs and debate sites, while writing blogs and entries on debate sites expects the the public to express their views in the "sharing participation mode" (Hirzalla \& van Zoonen, 2011, p. 486).

ANOVA analysis was performed with these selected variables of mediatized participation that address the dimension of online participation and information consumption described by Anduiza et al. (2012). The variable of getting news online shows the dimension of information consumption, while the variables of social network use, reading blogs and online debates, writing blogs, and participating in online debates describe the dimension of online participation. For the ANOVA analysis, variables that address minutes spent with these Internet practices were used as dependent variables. As we were interested if these online practices differ across digital mediascapes, the independent variable was a categorical variable that refers to digital mediascapes clusters.

Figure 1 shows large discrepancies between digital mediascape clusters in the duration of news consumption: the Eastern/Southern cluster diverges notably from the Western and Nordic. Internet users in the Eastern/Southern cluster seem to spend more time getting news online and using social network sites, but spend less time in deliberative activities of reading or writing blogs or contributing to debate sites.

ANOVA analysis confirmed a significant effect of the digital mediascapes clusters on online news consumption and writing entries on debate sites or blogs, and on using social network sites, but not on reading entries on debate sites and blogs. As the assumption of homogeneity of variance was violated, the Welch $\mathrm{F}$ ratio is reported for differences between country clusters in online news consumption 
$(\mathrm{F}=33.14, \mathrm{df}=1823, \mathrm{p}<0.01)$, writing entries at debate sites and blogs $(\mathrm{F}=25.91$, $\mathrm{df}=134.2, \mathrm{p}<0.01)$ and using social network sites $(\mathrm{F}=27.29, \mathrm{df}=2193.9, \mathrm{p}<0.01)$.

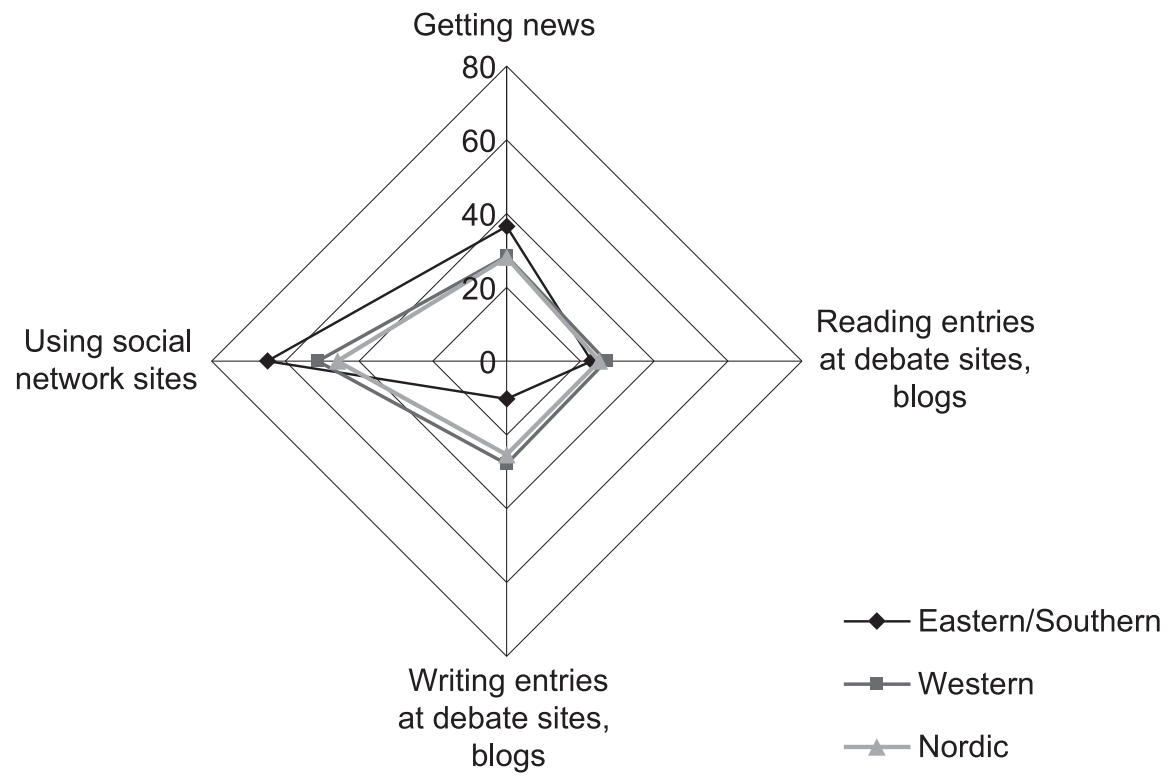

Figure 1. Mean values of mediatized participation and information consumption in three digital mediascapes

Source: Authors.

\section{DISCUSSION AND PRELIMINARY CONCLUSION}

In this study, we had set out to explore patterns of mediatized participation in three European digital mediascape models/clusters, based on representative surveys of online audiences conducted in 8 European Union Western European and Central and Eastern European member states. Mediatized engagement was defined to include the more active online practices of interaction, sharing, and creation, and more passive online practices of information consumption. Our aim was also to investigate how participation and information consumption practices vary in relation to the structural level of the media system. The model of digital mediascape from Peruško et al. (2015) which finds that Eastern and Western European country media systems cluster into three digital mediascapes - Nordic, Western and Eastern/Southern, was used to define the contemporary media system and used in the statistical analyses when looking at the impact of the structural level on mediatized practices.

Ten online practices were tested in a multi-level cross-national comparative design to answer our research questions in several connected steps. In answer to our first research question, the study discovered two distinct genres of mediatized 
engagement. Ten online practices of the composite European sample group into only two dimensions or genres of practice, the public connection and the personal connection (previous research finds more differentiated dimensions with fewer practices, Hirzalla \& van Zoonen, 2011). The public connection practices include three mediatized participation activities and one information consumption activity - getting news online, writing blogs and debate sites entries, reading blogs and discussions. Factor analysis showed that public/personal distinction defined differences in media uses, rather than the participation/consumption dimension. This might be an argument for including mediatized news consumption in the mediatized participation practices.

Our fourth mediatized participation practice - social networking - groups with the personal connection genre of media practice instead of the public connection genres. Social networking might be, like infotainment, a hybrid genre of media practice that "functions as both entertainment and news, simultaneously pop culture and public affairs" (Baym, 2005, p. 262). Our data don't tell us if social networks were used for political purposes (e.g., joining political groups or supporting political causes, sharing political information, communicating about politics or mobilizing other users in the network for political issues) or for personal connection, entertainment, or individual representation and identity building. Even regarding news seeking practice we cannot be sure what kind of news is included. This is of course the case with many studies of news consumption. In our study news consumption is clearly part of the public connection genres of mediatized practice which testifies of a relationship of the citizen/user to the wider society. The hybridization thesis regarding mediatized practices is supported also by recent research into online practices of co-creating and mashing-up of video spots with the purpose of making political statements, and creating spots from video games with the intent of political comment (Neys, 2015). This hybridity of online practices can be related to changes in communication-related practices linked with mediatization.

Answering our second research question, patterns of online participation and information consumption were found to vary in relation to the variations in different macro-institutional structures, beyond the influence of usual demographic variables of gender, age and education. Audiences in the Eastern/Southern cluster spend more time getting news online and using social network sites in comparison to audiences in the Western and Nordic digital media systems, but spend less time in deliberative activities of reading or writing blogs or contributing to debate sites, which are more prominent in the other two media system clusters. The study demonstrates the impact of the structural media system level on mediatized practices, which vary across the three digital mediascapes. A very interesting finding that merits further research is that the systemic structure has a more significant impact on the public connection genres of online practices, while the individual level variables impact more significantly the personal connection genres. Where we are 
seems to (in part) shape how we participate in the public world, while who we are influences our practices of entertainment and personal relations.

While some of the differences between practices in the South/Eastern and the other two clusters might be explained by new findings of the digital divide theory (that the skills gap lags the technology gap, van Deursen \& van Dijk, 2014, p. 508), we should keep in mind the significance of the systemic influence of digital mediascapes on mediatized participation. As the digital mediascapes model includes much more than the technology dimension (which is highlighted by the digital divide approach), we might seek the explanation there. Two dimensions are especially fruitful. First, in relation to the mediatization theory, the degree of commercialization of the media systems is linked with the more advanced stages of mediatization (Strömbäck, 2008; Udris \& Laucht, 2014). In the digital mediascapes, the Western cluster is the most commercialized (lower concentration of television audiences, higher values of cultural production). In this study, we find that the audiences in the Western cluster spend the most time on various online practices, as well as engaging in the most active participatory activities. This might point towards more advanced mediatization in the Western mediascape. Second, the highest inclusiveness of institutions is linked with overall political and economic openness and development (Acemoglu \& Robinson, 2012) which is along with the most developed digital media market found in the Nordic mediascape cluster. The post-socialist EU members, that have a relatively short democratic path, show lower levels on these dimensions than the countries in the other two mediascapes. These countries are also less affluent and their cultural industries are smaller. There is clearly a need for further in-depth research of digital mediascapes, and their impact on the practices of online participation.

While we show the influence of both individual level and structural level factors, the explained variance of online practices leaves room for more contextual influencers at work. For example, Taneja et al. (2012) show that media repertoires (of American audiences) are influenced by situational factors of social place/time of media use (i.e., work, leisure, travel). Aroldi et al. (2015) show that digital mediascapes as macro structural contexts also significantly influence the preferences for spaces/locations of media use. Despite the demonstrated robustness and statistical significance of our findings, we see the conclusions of our study as preliminary, since the findings open new questions that need further confirmation and explanation in mixed methods research designs and in-depth national and cross-national comparative research.

The contribution of this study is in situating the research on online media use into the framework of mediatized participation and citizen/audience practice especially with respect to the comparative position of new EU members. As the power of legacy media comes to be shared with online media and social networks, the power seeps also from the media organization to the audiences/citizens, giving 
their actions even more significance. How will this relationship develop in Central and Eastern Europe is today anybody's guess, and certainly an important area to continue to study.

\section{REFERENCES}

Aalberg, T., Aelst, P. van, \& Curran, J. (2010). Media systems and the political information environment: A cross-national comparison. The International Journal of Press/Politics, 15, pp. 255-271.

Anduiza, E., Jensen, M.J., \& Jorba, L. (2012). Digital Media and Political Engagement Worldwide. Cambridge-New Yok: Cambridge University Press.

Aroldi, P., Čuvalo, A., Micheli, M., Pasquali, F., Peruško, Z., Vittadini, N., \& Vozab, N. (2015). Spaces across Europe: Where people use media. Paper presented at the $65^{\text {th }}$ ICA Annual Conference "Communication across the Life Span", 20-25 May, 2015, San Juan, Puerto Rico.

Baym, G. (2005). The daily show: Discursive integration and the reinvention of political journalism. Political Communication, 22:3, pp. 259-276.

Blekesaune, A., Elvestad, E., \& Aalberg, T. (2012). Tuning out the world of news and current affairs - an empirical study of Europe's disconnected citizens. European Sociological Review, Vol. 28, Issue 1, pp. 110-126.

Boulianne, S. (2015). Social media use and participation: A meta-analysis of current research, information. Communication \& Society, 18:5, pp. 524-538.

Brüggemann, M., Engesser, S., Büchel, F., Humprecht, E., \& Castro, L. (2014). Hallin and Mancini revisited: Four empirical types of Western media systems. Journal of Communication, 64:6, pp. 1037-1065.

Cardoso, G. (2011). From mass to networked communication. In: S. Papathanassopoulos (ed.), Media Perspectives for the $21^{\text {st }}$ Century, New York: Routledge, pp. 117-136.

Carpentier, N. (2011). Media and Participation. A site of ideological-democratic struggle. Bristol: Intellect.

Castells, M. (2009). Communication Power. Oxford: Oxford University Press.

Couldry, N. (2012). Media, Society, World, Social Theory and Digital Media Practice. Cambridge: Polity Press

Couldry, N. (2014). Mediatization and the future of field theory. In: K. Lundby (ed.), Mediatization of communication. Berlin: De Gruyter, pp. 227-245.

Couldry, N., Livingstone, S., \& Markham, T. (2007). Media Consumption and Public Engagement: Beyond the Presumption of Attention. Basingstoke-New York: Palgrave MacMillian.

Curran, J., Iyengar, S., Lund, A.B., \& Salovaara-Moring, I. (2009). Media system, public knowledge and democracy: A comparative study. European Journal of Communication, 24:1, pp. 5-26.

Dahlgren, P. (2005). The internet, public spheres, and political communication: Dispersion and deliberation. Political Communication, 22:2, pp. 147-162.

Deursen, A. J. A. M. van, \& Dijk, J. A. G. M. van (2014). The digital divide shifts to differences in usage. New Media \& Society, 16(3), pp. 507-526.

Elvestad, E., \& Blekesaune, A. (2008). Newspaper readers in Europe: A multilevel study of individual and national differences. European Journal of Communication, 23:4, pp. 425-447.

Esser, F., \& Mathess, J. (2013). Mediatization effects on political news, political actors, political decisions and political audiences. In: H. Kriesi et al., Democracy in the Age of Globalization and Mediatization. Basingstoke: Palgrave Macmillan, pp. 177-201.

Esser, F., \& Strömbäck, J. (2014). Mediatization of Politics. Basingstoke: Palgrave Macmillan.

Hallin, D., \& Mancini, P. (2004). Comparing Media Systems: Three Models of Media and Politics. Cambridge: Cambridge University Press. 
Helles, R., Ørmen, J., Radil, C., \& Jensen, K. B. (2015). The media landscapes of European audiences. International Journal of Communication, 9, pp. 299-320.

Hirzalla, F., \& Zoonen, L. van (2011). Beyond the online/offline divide: How youth's online and offline civic activities converge. Social Science Computer Review, 29(4), pp. 481-498.

Hjarvard, S. (2008). The mediatization of society. A theory of the media as agents of social and cultural change. Nordicom Review, 29(2), pp. 105-134.

Jenkins, H. (2004). The cultural logic of media convergence. International Journal of Cultural Studies, 7, pp. 33-43, DOI: 10.1177/1367877904040603.

Jenkins, H. (2006). Convergence Culture. Where Old and New Media Collide. New York: New York University Press.

Jensen, H. (2015). Audiences across media. A comparative agenda for future research on media audiences. International Journal of Communication, 9, pp. 291-298.

Krotz, F. (2014). Mediatization as a mover in modernity: Social and cultural change in the context of media change. In: K. Lundby (ed.), Mediatization of Communication. Handbooks in Communication Science. Berlin-Boston: De Gruyter Mouton, pp. 131-162.

Livingstone, S. (2003). The changing nature of audiences: from the mass audience to the interactive media user. LSE Research Online. Retrieved on 18 February, 2016 from http://eprints.lse.ac.uk/ archive/00000417.

Livingstone, S. (2013). The participation paradigm in audience research. LSE Research Online. Retrieved on 19 February, 2016 from http:/eprints.ls.ac.uk/49630/.

Livingstone, S., \& Das, R. (2013). The end of audiences? Theoretical echoes of reception amid the uncertainties of use. LSE Research Online. Retrieved on 18 February, 2016 from http://eprints.lse. ac.uk/25116/.

Lundby, K. (2014). Mediatization of communication. In: K. Lundby (ed.), Mediatization of Communication. Berlin-Boston: De Gruyter Mouton, pp. 3-35.

Manovich, L. (2001). The Language of New Media. Boston: MIT Press.

Mazzoleni, G. (2014). Mediatization and political populism. In: F. Esser \& J. Strömbäck (eds.), Mediatization of Politics: Understanding the Transformation of Western Democracies. Basingstoke: Palgrave Macmillian, pp. 42-56.

Mazzoleni, G. Schulz, W. (1999). "Mediatization” of politics: A challenge for democracy?. Political Communication, 16:3, pp. 247-261.

Neys, J. (2015). Media practices that empower? Exploring remix and political agency. ECREA Communication and Democracy Section Conference: "Political Agency in the Digital Age". Copenhagen, 9-10 October 2015.

Nir, L. (2012). Cross-national differences in political discussion: Can political systems narrow deliberation gaps?. Journal of Communication, 62:3, pp. 553-570.

Papacharissi, Z., \& Mendelson, A. (2011). Toward a new(er) sociability: Uses, gratifications and social capital on Facebook. In: S. Papathanassopoulos (ed.), Media Perspectives for the $21^{\text {st }}$ Century. New York: Routledge, pp. 212-230.

Peruško, Z., Vozab, D., \& Čuvalo, A. (2013). Audiences as a source of agency in media systems: Postsocialist Europe in comparative perspective. Medialni Studia [Media Studies], 2, pp. 137-154.

Peruško, Z., Vozab, D., \& Čuvalo, A. (2015). Digital mediascapes, institutional frameworks, and audience practices across Europe. International Journal of Communication, 9, pp. 342-364.

Schulz, W. (2004). Reconstructing mediatization as an analytical concept. European Journal of Communication, Vol. 19, no 1, pp. 87-101.

Schulz, W. (2014). Mediatization and new media. In: F. Esser \& J. Strömbäck (eds.), Mediatization of Politics: Understanding the Transformation of Western Democracies. Basingstoke: Palgrave Macmillian, pp. 57-73. 
Shehata, A. (2010). Pathways to politics: How media system characteristics can influence socioeconomic gaps in political participation. The International Journal of Press/Politics, 15(3), pp. 295-318.

Shehata, A., \& Strömbäck, J. (2011). A matter of context: A comparative study of media environments and news consumption gaps in Europe. Political Communication, 28, pp. 110-134.

Shirky, C. (2008). Here Comes Everybody. The Power of Organizing Without Organizations. London: Penguin Group.

Strömbäck, J. (2008). Four phases of mediatization: An analysis of the mediatization of politics. The International Journal of Press/Politics, 13(3), pp. 228-246.

Taneja, H., Webster, J. G., Malthouse, E. C., \& Ksiazek, T. B. (2012). Media consumption across platforms: Identifying user-defined repertoires. New Media \& Society, 14(6), pp. 951-968.

Udris, L., \& Lucht, J. (2014). Mediatization at the structural level: Independence from politics, dependence on the market. In: F. Esser \& J. Strömbäck (eds.), Mediatization of Politics: Understanding the Transformation of Western Democracies. Basingstoke Palgrave Macmillian, pp. 114-136. 